\title{
Influence of bank concentration and institutions on capital structure: New international evidence
}

\section{Introduction}

Traditional analysis of determinants of capital structure has focused on firm characteristics mainly related to the extent of agency costs and asymmetric information (Jensen, 1986; Harris and Raviv, 1991).These studies have generally analyzed samples of US companies by comparing the trade-off theory (TOT) with the pecking order theory (POT). Recent papers argue that capital structure is affected not only by firmlevel variables, but also by country-level variables, or a firm's legal and institutional environment. ${ }^{1}$ We add to this growing literature. Our main contributions are analysis of: 1) how the determinants of firm leverage vary across countries depending on bank concentration and the legal and institutional system, and 2) how bank concentration interacts with the legal and institutional system to address conflicts of interest between shareholders and debtholders. This analysis lets us to examine the different validity of the TOT and POT across countries.

Empirical literature suggests that an effective legal system favors a firm's use of external funds, while companies in poorer contracting environments depend more on internal funds (Demirgüc-Kunt and Maksimovic, 1999; Qian and Strahan, 2007). A well-developed legal system affects not only the extent of external funding but also increases the proportion of long-term debt (Demirgüc-Kunt and Maksimovic, 1999; Giannetti, 2003; Fan et al., 2006).

\footnotetext{
${ }^{1}$ Secure property rights are associated with higher stock market values and a higher number of listed firms (La Porta et al., 1997), higher valuation of listed firms relative to their assets (Claessens et al., 2002; La Porta et al., 2002), greater use of external finance (La Porta et al., 1997, 1998, 2000), greater investments from external funds (Rajan and Zingales, 1998; Demirgüç-Kunt and Maksimovic, 1998), and higher improvements in performance of privatized firms (D’Souza et al., 2005; Boubakri et al., 2005).
} 
Most international studies in this area of research use country-level data. Rajan and Zingales (1995), Booth et al. (2001), Giannetti (2003), and Fan et al. (2006) use firmlevel data for cross-country comparisons of capital structure. Bae and Goyal (2004) and Qian and Strahan (2007) also analyze how country variables affect the characteristics of bank loans.

These papers offer mixed evidence on the influence of institutions on firm capital structure. Rajan and Zingales (1995) in an analysis of large listed companies in G-7 countries find that factors identified as cross-sectionally correlated with firm leverage in the United States are similarly correlated in other countries as well. Booth et al. (2001) suggest that the same determinants of capital structure prevail in ten developing countries. This research together suggests that institutional differences are unimportant in both developed and developing countries, although the authors compare separate regressions for each country and do not use explicit variables for the institutional environment in their estimations.

Giannetti (2003) explicitly introduces creditor right protection in the analysis of a sample of listed and unlisted companies in eight European countries. Her results suggest that the relevance of institutional variables depends on firm size. Larger listed companies have easier access to international financial markets, so their corporate finance decisions are less subject to the institutional constraints in domestic markets. Institutional characteristics, however, have a greater impact in unlisted companies. For these companies, stronger creditor protection makes loans for investing in intangible assets more available and guarantees access to long-term debt for firms in sectors with highly volatile returns. Fan et al. (2006) find that institutional factors are critical determinants of firm capital structure in a cross-section of 39 developed and developing countries. A country's legal and tax system, level of corruption, and the availability of 
information intermediaries explain a significant portion of the cross-country variation in leverage. Firms in common law countries, for example, have less leverage and use more long-term debt.

Finally, Bae and Goyal (2004) and Qian and Strahan (2007) show the relevance of institutional conditions for terms of bank loans. Bae and Goyal (2004) find lenders charge lower spreads on loans in countries with stronger property rights protection, while the latter find that stronger creditor rights enhanced loan availability.

Our work makes several contributions to this literature. First, we analyze the influence of bank concentration and institutional characteristics not only on firm leverage but also on the firm-level determinants of leverage. Our analysis shows that either the pecking order or trade-off theories apply differently across countries, depending on institutions and bank concentration. Weaker protection of property rights increases the agency cost of external funds, leading to the preferential use of internal funds as posited by the POT. The TOT, however, is more valid in countries with stronger protection of property rights.

Second, we analyze the interaction of bank concentration with a country's legal and institutional system (protection of property and creditor rights) to reduce agency costs and mitigate information asymmetries between shareholders and debtholders. The results suggest that greater bank concentration can substitute for creditor protection and asset tangibility to reduce the agency cost of debt.

Third, we analyze more countries than most previous studies. We include a sample of 12,049 firms in 39 countries over the period 1995-2004 (the same number of countries as Fan et al., 2006), compared to seven countries in Rajan and Zingales (1995), eight countries in Giannetti (2003), and ten in Booth et al. (2001). We thus can provide information on a greater range of institutional differences to give us a deeper 
understanding of how capital structure depends on institutions and on bank concentration.

Finally, we account for dynamic processes in firm leverage using generalized-methodof-moments (GMM) estimators developed by Arellano and Bond (1991) for dynamic panel data. GMM models are designed to handle autoregressive properties in the dependent variable (firm leverage) when lagged values are included as explanatory variables and endogeneity in the explanatory variables (other firm-specific characteristics) must be controlled for. Although the GMM method has been used in studies on capital structure focusing on a single country, it has not yet been applied in studies using international data. ${ }^{2}$

The rest of the paper is organized as follows. Section 2 discusses the influence of bank concentration and institutions on the determinants of firm capital structure and the hypotheses tested in the paper. Section 3 describes the characteristics of the database and methodology, while Section 4 discusses the empirical results. Section 5 checks the robustness of our basic results. Finally, Section 6 concludes the paper.

\section{Theoretical background and hypotheses}

There are two competing but not mutually exclusive financial models based on firm variables to explain financing decisions: trade-off theory (TOT) and pecking order theory (POT). The TOT posits that firms maximize their value when the benefits of debt (the tax shield, its disciplinary role or the reduction of free cash flow problems and its advantage over outside equity in terms of information costs) equal the marginal cost of debt (bankruptcy costs and agency costs between shareholders and debtholders).

\footnotetext{
${ }^{2}$ Cheung and Wei (2006) point out that omitting adjustment costs in the model specification biases the analysis of the relation between insider ownership and corporate performance. Shyam-Sunder and Myers (1999), Fama and French (2002), and Flannery and Rangan (2006), among others, obtain results consistent with partial adjustment to the target leverage.
} 
The POT, developed by Myers (1984) and Myers and Majluf (1984), focuses on the information asymmetries between firm insiders and outsiders. It assumes managers use private information to issue risky securities when the firm is overvalued. Investors are aware of this asymmetric information problem, and they discount the price of a firm's new and already issued risky securities when new issues are announced. Managers anticipate these price discounts, and may forgo profitable investments if they must finance them with new risky securities. To avoid this distortion of investment decisions, managers prefer to finance projects with retained earnings which do not involve the asymmetric information problem associated with risky debt. Without enough retained earnings, they will use debt financing; an equity issue would be the least favored option. This means that changes in a firm's leverage are driven not by the costs and benefits of debt according to the trade-off model, but rather by the firm's net cash flows (cash earnings minus investment outlays) and the degree of information asymmetry.

Table 1 summarizes the traditional arguments of the POT and the TOT for the effects of these firm characteristics on leverage (Myers, 1977; Jensen, 1986; Stulz, 1990; Rajan and Zingales, 1995; Flannery and Rangan, 2006). The POT model suggests that a firm's debt drops with profitability but increases with growth opportunities and intangible assets. The TOT, on the other hand, suggests that a firm's debt rises with profitability and drops with growth opportunities and intangible assets.

\section{INSERT TABLE 1 ABOUT HERE}

We argue that the TOT or POT may apply differently across countries as the information asymmetries and agency costs vary depending on the quality of a country's legal and institutional system (protection of property rights and creditor rights) and on its bank market concentration.

\section{a) Property rights}


Weak protection of property rights means investors are less likely to enter into private contracts, which makes information asymmetry more relevant, increasing problems of adverse selection and moral hazard. As equity issue is subject to more problems of information asymmetry than debt, we would expect stronger protection of property rights to favor increased use of equity over debt.

This prediction is consistent with the empirical literature suggesting that weak legal systems and poor institutional infrastructure impede market functioning. La Porta et al. (1997, 1998) find that markets develop better in countries that protect the rights of minority shareholders. Levine $(1998,1999)$ and Rajan and Zingales (1998) argue that bank-based architecture survives and is more effective in countries with weaker legal and institutional systems because banks, in the absence of effective legal provision, have enough power to protect their interests. Hence, market-based systems work better and equity issues may be more frequent in a more protective contractual environment. The first hypothesis is:

H.1: Better protection of property rights favors the issue of equity and is, therefore, negatively related to firm leverage.

The protection of property rights may also affect firm-level determinants of capital structure. In a poor contracting environment, where investors cannot solve the conflicts of interest associated with information asymmetries, firms are more likely to favor the use of internal funds as it is more difficult for them to use external funds. In countries with poor contracting environments, we would therefore expect the POT arguments to prevail. In these countries firm leverage would be more negatively (less positively) related to profitability and asset tangibility but more positively (less negatively) related to growth opportunities. 
In countries with a better contracting environment, however, the enforceability of contracts would allow counterparties themselves to resolve conflicts stemming from information asymmetry. Nonetheless, there would always be unresolved conflicts within the incomplete contracts framework. The intensity of these would depend on the characteristics of the particular firms. Companies with more tangible assets could offer greater guarantees to reduce the cost of debt and could borrow more than firms with fewer tangible assets. In countries with better contracting environments, we would therefore expect the TOT arguments to prevail.

According to this argument, the second hypothesis is:

H.2: The TOT (POT) is better able (less able) to explain the determinants of firm leverage with a country's protection of property rights.

\section{b) Creditor rights}

We include a creditor rights index to see whether differences in firm leverage across countries are associated with differences in the legal protection of creditors. Empirical evidence suggests a positive relation between the protection of creditors and firm debt. Levine $(1998,1999)$ uses country-level data to find that banks develop better in countries that better protect the rights of secured creditors. Giannetti (2003) reports that unlisted firms investing in intangible assets in countries with good creditor protection find it easier to obtain loans. Demirgüc-Kunt and Maksimovic (1999) and Giannetti (2003) show that institutions that favor creditor rights and ensure stricter enforcement are associated not only with higher leverage but also with wider availability of longterm debt. Qian and Strahan (2007) find that strong creditor protection is associated with longer-term lending and lower interest rates. 
The protection of creditor rights may also affect firm-level determinants of capital structure. When creditors are not sufficiently protected by law, it will be harder for firms with higher agency cost of debt to get a loan because banks anticipate, all else equal, more problems of underinvestment and risk-shifting. Better protection of creditor rights may mitigate these conflicts and thereby improve access to credit for firms investing in intangible assets, with low profitability, and high growth opportunities. Thus, we expect the trade-off theory to be less valid in countries with better protection of creditor rights. Evidence consistent with the greater availability of debt for firms investing in intangible assets is found by Giannetti (2003) in countries with good protection of creditor rights.

The third hypothesis is:

H.3: The TOT is less able to explain the determinants of firm leverage with a country's protection of creditor rights.

\section{c) Bank market concentration}

The banking literature suggests two possibly opposing effects of bank concentration on firm leverage. In a market without information asymmetries, where agents have perfect information on the quality of goods being exchanged, market power results in a higher price for credit and less credit availability. Following this argument, a negative relation might be expected between bank concentration and firm leverage.

In markets with asymmetric information, however, higher bank market concentration may increase incentives of banks to invest in the acquisition of soft information by establishing close relationships with borrowers over time (relationship banking), facilitating the availability of credit, thereby reducing firms' financial constraints (Boot, 
2000; Dell'Aricia and Marquez, 2004). The importance of bank concentration in determining the value of lending relationships was first articulated by Petersen and Rajan (1994, 1995). They offer evidence from small business data indicating that creditors are more likely to finance credit-constrained firms when credit markets are concentrated because it is easier for these creditors to internalize the benefits of assisting the firms. They also show that building close ties with an institutional creditor is valuable for firms and appears to operate more through quantities rather than prices. Following this argument, a positive relation would be expected between bank market concentration and firm leverage.

Empirical evidence on the influence of bank concentration on debt availability is mixed. Like Petersen and Rajan (1994, 1995), Berlin and Mester (1999) show in the US that firms in less concentrated credit markets are subject to greater financial constraints. However, D'Auria et al. (1999) in Italy and Degryse and Ongena (2005) in Belgium find that greater bank market concentration raises the cost of bank financing. Cetorelli and Gambera (2001) also provide mixed evidence on the effect of bank concentration on economic growth. While it generally has a negative effect on growth, it also promotes growth of industrial sectors that are more in need of external finance by facilitating credit access for younger firms. The opposing arguments and mixed empirical evidence mean that the influence of bank market concentration on firm leverage is basically an empirical question.

We contribute to this literature by analyzing how the influence of bank concentration on firm leverage may vary with a country's legal and institutional environment. Our hypothesis is that the positive effect of bank concentration on firm's leverage, suggested by relationship banking, may be greater in countries with less stringent protection of property and creditor rights. The difficulty for development of markets in such 
environments may promote long-term relationships between banks and debtors ( $\mathrm{La}$ Porta et al., 1997, 1998). Bank concentration in these markets may favor these relationships and have a positive effect on firm debt. Bank concentration in underdeveloped markets may therefore substitute good legal protection of creditors and property and operate in the absence of strong institutions to reduce information asymmetries and agency costs between banks and firm owners. In developed markets, however, private contracting conflicts may be solved by smooth functioning institutions, and concentration is no longer useful for promoting the long-term relationships that then become less beneficial.

Following this argument, we establish the fourth hypothesis:

\section{H.4: Bank concentration has a more positive effect (or a less negative effect) on firm leverage in countries with less developed legal and institutional environments.}

Bank concentration may also influence firm-level determinants of leverage. We expect higher bank concentration to reduce the importance of pecking order theory arguments by mitigating problems of information asymmetry between firms and bank lenders. Reduced information asymmetries make it easier for less profitable firms with fewer tangible assets to use debt. Higher bank concentration and long-term relationships between banks and debtholders would also make the trade-off theory less valid by reducing agency costs. Lower agency costs make firms' profitability and tangibility less important in facilitating access to debt. As we expect higher concentration to reduce the validity of both the POT and the TOT, we cannot make a clear forecast for the influence of bank concentration on the traditional firm-level determinants of debt, and therefore we analyze it as an empirical question. 


\section{Econometric specification and database}

\section{A. Methodology}

We adopt the traditional dynamic model of capital structure that researchers have used in prior studies of a single country. The model tests whether there is a leverage target and, if so, how quickly a firm moves toward the target. The form of the target adjustment model states that changes in the debt ratio $\left(D_{i t}-D_{i t-1}\right)$ partially absorb the difference between the target leverage $\left(D_{i t}{ }^{*}\right)$ and lagged leverage $\left(D_{i t-1}\right)$ :

$$
\left(D_{i t}-D_{i t-1}\right)=\alpha\left(D_{i t}^{*}-D_{i t-1}\right)
$$

where the transaction costs that impede complete adjustment to the target leverage are measured by the coefficient $\alpha$, which varies between 0 and 1 and is inversely related to adjustment costs. If transaction costs are zero, i.e., $\alpha=1, \mathrm{D}_{\mathrm{it}}=\mathrm{D}_{\mathrm{it}}{ }^{*}$, and firms automatically adjust their debt level to the target level. So, firm leverage is:

$$
D_{i t}=\alpha D_{i t}^{*}+(1-\alpha) D_{i t-1}
$$

As the target debt is unobservable, we model it as a linear function of the traditional determinants of capital structure as indicated by Rajan and Zingales (1995) (profitability, growth opportunities, tangible assets, and size), obtaining: ${ }^{3}$

$$
D_{i t}^{*}=a_{0}+a_{1} P_{R O F_{i t}}+a_{2} G R O W T H_{i t}+a_{3} P P E_{i t}+a_{4} S I Z E_{i t}+\mu_{i t}
$$

Incorporating Equation (3) into Equation (2) and considering that estimations are carried out with panel data, we get:

$$
\begin{aligned}
& D_{i t}=\alpha a_{0}+(1-\alpha) D_{i t-1}+\alpha a_{1} \text { PROF }_{i t}+\alpha a_{2} \text { GROWTH }_{i t}+\alpha a_{3} \text { PPE }_{i t}+\alpha a_{4} \text { SIZE }_{i t}+ \\
& +b_{5} \text { CONC }_{k t}+b_{6} \text { RIGHTS }_{k t}+b_{7} \text { CREDITORS }_{k}+\sum_{k=1}^{m} C_{k}+\sum_{t=1995}^{2004} Y_{t}+\sum_{j=1}^{n} I_{j}+\gamma_{i}+\mu_{i t}
\end{aligned}
$$

\footnotetext{
3 Other authors using this framework include Miguel and Pindado (2001), Ozkan (2001), Gaud et al. (2005), and Flannery and Rangan (2006).
} 
In addition to firm-level variables, we also included bank market concentration (CONC), protection of property rights (RIGHTS), and protection of creditor rights (CREDITORS) in each country. $\sum_{k=1}^{m} C_{k}$ is the set of country dummy variables controlling for other legal and institutional aspects beyond those explicitly included in RIGHTS and CREDITORS. $\sum_{t=1995}^{2004} Y_{t}$ is a set of dummy time variables for each year capturing any unobserved firm-invariant time effect not included in the regression. We also include industry dummy variables according to SIC code $\left(\sum_{j=1}^{n} I_{j}\right)$ to capture any industry effect not included in the explanatory variables. $\gamma_{i}$ is the firm effect, which is assumed to be constant for firm i over $\mathrm{t}$; and $\mu_{i t}$ is the error term.

We apply generalized-method-of-moments (GMM) estimators developed for dynamic models of panel data by Arellano and Bond (1991). This methodology is specifically designed to address three particular econometric issues: (i) the presence of unobserved firm-specific effects, eliminated by taking first differences of the variables; (ii) the autoregressive process in the data regarding the behavior of the leverage ratio (i.e., the need to use a lagged-dependent-variables model to capture the dynamic nature of the capital structure decisions); and (iii) the likely endogeneity of the explanatory variables. We control for the potential endogeneity of PROF, GROWTH, PPE, and SIZE in the GMM estimations by using two- to four-period lags of the same variables as instruments. The country and the dummy variables are initially considered exogenous. We check later to see that results do not change when we consider the potential endogeneity of the legal and institutional variables. 
We use one-step estimation and specify the robust estimator of the variance-covariance matrix of the parameters. We also examine the hypothesis that there is no second-order serial correlation in the first-difference residuals $\left(m_{2}\right)$. In our models this hypothesis of the absence of second-order serial correlation is not rejected. First-order serial correlation $\left(m_{1}\right)$ in the differentiated residuals is attributable to the first difference of models.

\section{B. Database}

We obtain firm balance-sheet and income-statement annual data (in euros and in real prices) from Worldscope for 1995-2004. We initially selected the 49 countries considered by La Porta et al. (1998), but then eliminated 10 of them because of scarce data: Colombia, Ecuador, Egypt, Jordan, Kenya, Nigeria, Sri Lanka, Uruguay, Venezuela, and Zimbabwe. The final number of countries considered is therefore 39, including both developed and developing countries.

We exclude firms whose capital decisions may reflect special factors: the financial industry (SIC codes 6000 - 6999) and regulated enterprises (SIC codes 4000 - 4999). Since we apply the GMM first-difference estimator with one lag of the dependent variable in the empirical analysis, firms with fewer than three consecutive years of data must be excluded. There are ultimately 12,049 firms included in the sample and 59,577 firm-year observations.

Following Titman and Wessels (1988), Demirgüc-Kunt and Maksimovic (1999), and Booth et al. (2001), our proxy for leverage is the ratio between long-term debt and the market value of assets. ${ }^{4}$ Market value of assets is defined as total assets minus book

\footnotetext{
${ }^{4}$ Welch (2004) argues that we should use market leverage ratios since our theories of target ratios are implicitly about market leverage ratios. Many other researchers analyze market value debt ratios, such as Hovakimian et al. (2001), Fama and French (2002), Barclay et al. (2003), Leary and Roberts (2005), and Flannery and Rangan (2006).
} 
value of equity plus market value of equity. Long-term debt is the debt that is most sensitive to the problems of adverse selection and moral hazard. By using it as a dependent variable, we aim to better understand the effect of bank concentration and institutions on the resolution of such problems between firms and debtholders. We check the robustness of the results using total debt.

Profitability (PROF) is measured as earnings before interest and taxes plus depreciation expenses and provisions (non-cash deductions from earnings) divided by total assets (Miguel and Pindado, 2001; Ozkan, 2001; Gaud et al., 2005). Following Rajan and Zingales (1995), Gaud et al. (2005), and Flannery and Rangan (2006), we measure growth opportunities (GROWTH) as the market-to-book ratio. We proxy the tangibility of assets by the percentage of property, plant, and equipment in total assets (PPE). This variable is used by Titman and Wessels (1988) as an indicator that is positively related to the collateral value.

Larger firms tend to be more diversified, and size may be an inverse proxy for the probability of bankruptcy. Many authors thus suggest that firm size is positively related to the leverage ratio (Rajan and Zingales, 1995; Booth et al., 2001; Frank and Goyal, 2003; Gaud et al., 2005). However, there are assumed to be fewer information asymmetries between insiders in a firm and the capital markets for larger firms. Large firms should thus be more able to issue informationally sensitive securities like equity, and should have less debt. We measure size by the natural logarithm of total sales (Titman and Wessels, 1988; Rajan and Zingales, 1995; Gaud et al., 2005).

We follow Demirgüc-Kunt et al. (2004) and Beck et al. (2006) and measure bank concentration as the fraction of bank assets held by the three largest commercial banks in the country. Figures are obtained from the World Bank Database, whose main source is Fitch IBCA's Bankscope Database. 
We measure the protection of property rights by the index of private property rights published by the Heritage Foundation. This is an annual indicator of the degree to which private property rights are protected and the degree to which the government enforces laws that protect private property. It also accounts for the possibility that private property may be expropriated, and analyzes the independence of the judiciary, corruption within the judiciary, and the ability of individuals and businesses to enforce contracts. This index ranges between 1 and 5; a high score indicates greater legal protection of property (we reverse the scale of the original index).

We use the index developed in La Porta et al. (1998) to measure a borrower country's overall creditor rights. This index is equal to the sum of the scores ( 0 to 1$)$ for five categories: no automatic stay on assets, payment of secured creditors first, restrictions on reorganization, restrictions on management during reorganization, and legal reserves required as a percentage of capital. This index thus ranges from 0 to 5 , with higher values indicating stronger creditor rights or stronger protection against borrower expropriation.

Table 2 shows for the total sample a mean leverage ratio of $15.33 \%$, with an average profitability of $8.48 \%$ and a mean for growth opportunities of 2.67 . The companies in the sample have a $32.63 \%$ ratio of property, plant, and equipment to total assets. Market leverage ratios vary considerably across countries from $26.15 \%$ in India to $7.62 \%$ in Turkey.

Table 2 also presents mean values for CONC, RIGHTS, and CREDITORS. Bank concentration varies greatly across countries. In Finland and Sweden, three banks account for almost all bank assets. In countries such as the US or Taiwan, the percentage of bank assets held by the three largest commercial banks was less than $30 \%$. 


\section{(INSERT TABLE 2 ABOUT HERE)}

Table 3 reports the correlation matrix. Long-term leverage and total leverage are highly correlated. According to most of the previous empirical evidence, debt ratios are positively correlated with firm size. A positive correlation of market long-term leverage with profitability and tangible assets and a negative correlation with growth opportunities are consistent with predictions of the trade-off theory. Moreover, country variables (CONC, RIGHTS, CREDITORS) are negatively correlated with the long-term debt ratio.

(INSERT TABLE 3 ABOUT HERE)

\section{Results}

Table 4 compares results obtained by Rajan and Zingales (1995) in the seven major industrialized countries and the results we obtain for these countries as we replicate their methodology and also apply the generalized method of moments.

\section{(INSERT TABLE 4 ABOUT HERE)}

Ordinary least squares results in our database agree those reported by Rajan and Zingales (1995), except for Germany, France, and Italy, for which Rajan and Zingales (1995) have fewer observations. Our estimations show that profitability has a negative influence on leverage in all countries, while tangibility and size have a positive effect. The market-to-book ratio has a negative coefficient in all countries, except in the US and France. Rajan and Zingales (1995) also showed growth has a negative influence on borrowing in these two countries.

The greatest differences come from applying GMM instead of ordinary least squares. Although profitability continues to have a negative influence on debt, with the 
exception of Italy, size, tangibility, and growth tend not to have a significant influence on the level of borrowing in the seven countries. This indicates differences resulting from the use of a partial-adjustment model where some of the variation in the dependent variable is absorbed by the lagged dependent variable.

We also estimate Equation [4] separately for each country in order to analyze the stability of firm-level determinants across countries. Results in Table 5 indicate changes in the signs and significance of firm-level determinants of leverage across countries. The traditional negative relation between leverage and profitability found by Rajan and Zingales (1995), Booth et al. (2001), and Giannetti (2003) is statistically significant in 17 of the 39 countries. Growth has significant negative coefficients in only 7 countries and non-significant coefficients in the other countries. There is even more cross-country variation in signs in the estimated coefficients for asset tangibility. PPE in 16 of the 39 countries has the traditional positive coefficient found in previous research, but a negative coefficient in three countries (Belgium, Italy, and Mexico); in 20 countries there are no significant coefficients.

Variations across countries in the determinants of capital structure are consistent with the idea that country variables like bank concentration and the institutional environment are relevant for the level and determinants of debt. We analyze this possible relevance in Tables 6 through 8.

\section{(INSERT TABLE 5 ABOUT HERE)}

Table 6 shows the results of the partial-adjustment model [4] for the whole sample of firms. The coefficients of time, country, and industry dummies are not reported to save space. The positive and statistically significant coefficients of $\mathrm{DEBT}_{\mathrm{t}-1}$ suggest that firms have a target leverage to which they partially adjust in each period. Coefficients of 
$\operatorname{DEBT}_{\mathrm{t}-1}$ take values of around 0.66 , which implies values of $\alpha$ of approximately 0.34 .

This value is similar to those reported by Flannery and Rangan (2006), where the mean US firm converges toward its long-run target at a rate of $30 \%$ per year. ${ }^{5}$

\section{(INSERT TABLE 6 ABOUT HERE)}

The relation between leverage and profitability of the firm is negative for all estimations in Table 6. This is the result most frequently found in the single-country regressions of Table 5 and is consistent with the pecking order theory because higher profitability increases the possibility of retaining earnings and reduces, all else being equal, the need for debt.

Size has a positive impact on firms' debt, which is consistent with size being an inverse proxy for the probability of bankruptcy. This result is similar to results shown in Rajan and Zingales (1995), Fama and French (2002), Frank and Goyal (2003), Flannery and Rangan (2006), and Gaud et al. (2005).

Coefficients for growth opportunities and the tangibility of assets are not statistically significant at standard levels, although their signs are consistent with the traditional arguments of the trade-off theory. The negative coefficients for growth opportunities reflect higher agency costs between shareholders and debtholders and higher costs of financial distress. The positive coefficients of PPE in all the estimations seem to be consistent with the greater value of these assets as collateral.

Like other authors who have tested TOT and POT, in this international sample we do not find results that validate the predominance of one theory over the other; that is, the results are partially consistent with both theories. ${ }^{6}$

\footnotetext{
5 Jalivand and Harris (1984), Shyam-Sunder and Myers (1999), and Flannery and Rangan (2006) find values of $\alpha$ ranging between 0.30 and 0.70 for the US; Kremp et al. (1999) find a value of 0.53 for German firms and a value of 0.28 for France; Ozkan (2001) finds values between 0.52 and 0.57 for a panel data set of UK companies; Miguel and Pindado (2001) find an $\alpha$ of 0.79 for a panel data set for Spanish companies; and Gaud et al. (2005) finds values of between 0.14 and 0.29 for the Swiss market.
} 
The influence of bank concentration on debt ratio is positive, consistent with evidence initially provided by Petersen and Rajan $(1994,1995)$ in support of the fact that concentrated credit markets make lending relationships more valuable and thus improve access to loans.

The variable proxying for the protection of property rights has negative coefficients in all estimations. This result is consistent with our hypothesis H.1 and with lower agency costs associated with equity issues in countries with stronger protection of property rights. This result complements the evidence provided by Bae and Goyal (2004) to the effect that stronger protection of property rights reduces loan spreads in international bank loans. Our finding suggests that protection of property rights has a more positive influence on equity than on debt. This conclusion is consistent with the higher leverage and shorter debt maturity found by Fan et al. (2006) in countries with high levels of corruption.

The positive coefficients for CREDITORS in columns (5) and (6) confirm that legal protection of creditor rights can reduce the agency cost of debt, as documented by Demirguc-Kunt and Maksimovic (1999) and Giannetti (2003). Our result is also consistent with the lower interest rates and longer maturities of bank loans found by Qian and Strahan (2007) in countries with strong legal protection of creditors.

\section{A. Interaction of bank concentration with the legal and institutional environment}

To analyze whether bank concentration substitutes for good legal protection of creditor and property rights to reduce conflicts of interest between banks and firms, we interact CONC with RIGHTS and with CREDITORS in Table 7.

\footnotetext{
${ }^{6}$ While Shyam-Sunder and Myers (1999) and Fama and French (2002) obtain results that are consistent with the predominance of the POT in the US, Flannery and Rangan (2006) suggest the TOT is more valid. Frank and Goyal (2003) and Leary and Roberts (2005) obtain evidence that supports both theories.
} 
The coefficients of CONCxRIGHTS in columns (1) and (2) are not statistically significant, suggesting that the positive influence of protection of property rights on equity issues is independent of bank concentration. Columns (3) and (4) show negative coefficients for the interaction term CONCxCREDITORS. This means that the higher the bank concentration, the lower the positive effect of creditor protection on firm leverage. This result is consistent with our hypothesis H.4, suggesting that bank concentration substitutes for strong protection of creditor rights to reduce information asymmetries and agency costs between shareholders and debtholders; that is, bank concentration is an alternative for facilitating access to debt in countries with weak protection of creditor rights. This effect is also economically significant. For instance, using the coefficients in column (4) of Table 7, a one standard deviation increase in bank concentration (19.09) would cause a reduction in the positive influence of legal protection on leverage which represents 0.317 times the standard deviation of the longterm debt ratio.

\section{INSERT TABLE 7 ABOUT HERE}

\section{B. Variation across countries of firm-level determinants of leverage}

Differences in bank market concentration and institutional characteristics in a country that affect firm-level determinants of leverage might explain differences across countries in the predominance of the trade-off theory versus pecking order theory. We analyze this possibility by including interaction terms between each country variable (bank concentration, property rights, and creditor rights) and the firm-level determinants of capital structure. Results are reported in Table 8.

\section{INSERT TABLE 8 ABOUT HERE}


The positive coefficient of PPE in column (1) is consistent with the idea that asset tangibility mitigates the agency cost of debt, as suggested by the TOT. The negative coefficients for CONCXPPE, however, indicate that higher market concentration makes asset tangibility less important in gaining access to debt. That is, close relationships between banks and borrowers resulting from high bank concentration may make debt more available to firms with intangible assets by reducing the agency costs associated with the use of that debt. This result suggests that asset tangibility and bank market concentration are substitutes for reducing the agency cost of debt and that bank concentration makes the TOT less valid.

Column (2) reports the results of interactions between RIGHTS and firm-level determinants of leverage. Coefficients of the interaction terms are consistent with the prediction in $\mathrm{H} .2$ because they suggest that the TOT becomes more valid with the protection of property rights. The positive coefficients on RIGHTSxPROFIT and RIGHTSxPPE indicate that greater protection of property rights increases the positive effects of profitability and asset tangibility on firm access to debt suggested by the TOT. This means that in poorer institutional environments it is more difficult for all firms, regardless of their profits and tangible assets, to solve the moral hazard and adverse selection problems associated with private transactions. These higher agency costs and information asymmetries make it more difficult for firms in poor institutional environments to obtain external funds, and the POT propositions are more valid. Coefficients of the interaction of CREDITORS with PROFIT, GROWTH, and PPE in column (3) are not statistically significant. As CREDITORS maintains the positive coefficient observed in all the previous estimates, our results suggest that creditor protection has a positive effect on the level of debt but does not affect firm-level 
determinants of leverage or the relative importance of the TOT and POT for explaining capital structure.

Column (4) confirms that results do not change when we simultaneously include in the regression all the interaction terms found to be statistically significant in previous estimations.

\section{Robustness}

In further analysis we check the robustness of the results. First, we replicate estimations using as the dependent variable total market leverage defined as the ratio of long- and short-term debt and the market value of assets. The results reported in Table 9 confirm most of the findings so far using long-term debt. Column (2) shows that leverage declines with the protection of property rights and increases with the protection of creditor rights. Columns (4) and (5) indicate that bank concentration substitutes for creditor protection and asset tangibility, and the TOT propositions are more valid in stronger institutional environments. The positive effect of bank concentration on longterm debt is observed only in countries with lower protection of creditor rights when we use total debt. The results for total debt should be treated with caution, however, because $m_{2}$ rejects in four estimations the null hypothesis of the absence of second-order serial correlation in the first-difference residuals.

\section{INSERT TABLE 9 ABOUT HERE}

Second, we control for the potential endogeneity of bank concentration and institutional country variables. Instead of the observed values of each country variable, we use instruments for them to identify their exogenous component and to control for potential simultaneity bias. The instruments used, following Barth et al. (2004), are: legal origin dummy variables (English, French, German, and Scandinavian), latitudinal distance 
from the equator, and religious composition dummy variables. Religious composition is measured as the percentage of the population in each country that is Roman Catholic, Protestant, Muslim, or “other.” Results do not change.

Third, we check that results do not change when we use different proxies for legal and institutional variables. Results do not change when both RIGHTS and CREDITORS are multiplied by the law and order index of the International Country Risk Guide (ICRG) to more specifically incorporate differences in law enforcement across countries.

Another alternative to the measure of property rights is the Index of Economic Freedom published by the Heritage Foundation. Economic freedom is defined as the absence of government coercion or constraints on the production, distribution, or consumption of goods and services beyond the extent necessary for citizens to protect and maintain liberty itself. The index comprises ten categories of economic freedom: trade policy, fiscal burden of government, government intervention in the economy, monetary policy, capital flows and foreign investment, banking and finance, wages and prices, property rights, regulation, and informal market activity. Results using this index are not significantly different from those reported using the property rights index.

\section{Conclusions}

We conclude that bank concentration and institutions affect capital structure and firmlevel determinants of leverage in a study using a panel database of 12,049 firms in 39 countries during the period from 1995 to 2004. Bank market concentration expands firms' access to long-term debt, as relationship banking serves to mitigate information asymmetries and agency costs between banks and debtors.

Our results also confirm that the protection of creditor rights facilitates the use of longterm debt by firms; stronger protection of property rights promotes the issue of equity 
and reduces leverage ratios. Bank market concentration can substitute for the legal protection of creditor rights and the tangibility of firms' assets to reduce the agency cost of debt. So, the weaker the protection of creditors in a country and the more intangible firms' assets, the greater the positive marginal effects of bank concentration on firm debt. This result implies that bank concentration, the protection of creditor rights, and asset tangibility are alternative mechanisms for facilitating access to debt for firms.

Finally, we provide arguments to explain the variation across countries in the applicability of the trade-off and pecking order theories. As bank concentration and institutional country characteristics modify agency costs and information asymmetries between firms and banks, the firm-level determinants of leverage also vary across countries. Results indicate that weaker protection of property rights increases the agency cost of external funds, leading to preferences for the use of internal funds as proposed by the POT, while the TOT propositions are more valid in countries with stronger protection of property rights.

\section{Acknowledgments}

We are grateful to participants in the ACEDE Conference at Seville (2007), an anonymous referee and the editor for their helpful comments and suggestions. Financial support from the Regional Government of Asturias, Project IB05-183, and from the Ministry of Science and Technology of Spain (MCT) - ERDF, Project MEC-06-SEJ 2006-15040-C02-01 is gratefully acknowledged. This project was also made possible by a grant from the ERDF (FEDER-05-UNOV05-23-017) for acquisition of Worldscope. A previous version of this paper has been published as the working paper $n^{0} 372 / 2008$ of working paper series of the Fundación de las Cajas de Ahorros (FUNCAS).

\section{References}

Arellano, M., Bond, S.,1991. Some tests of specification for panel data: Monte Carlo evidence and an application to employment equations. Review of Economic Studies 58, 277-297.

Bae, K.H., Goyal, V.K., 2004. Property rights protection and bank loan pricing. Working paper.

Barclay, M.J., Marx, L.M., Smith, C.W., 2003. The joint determination of leverage and maturity. Journal of Corporate Finance 9 (2), 149-167. 
Barth, J.R., Caprio, G., Levine, R., 2004. Bank regulation and supervision: What works best?. Journal of Financial Intermediation 13, 205-248.

Beck, T., Demirgüç-Kunt, A., Levine, R., 2006. Bank concentration, competition, and crises: First results. Journal of Banking and Finance 30, 1581-1603.

Berlin, M., Mester, L.J., 1999. Deposits and relationship lending. The Review of Financial Studies 12, 579-607.

Boot, W., 2000. Relationship banking: what do we know? Journal of Financial Intermediation 9, 7-25.

Booth, L., Aivazian, V., Demirguc-Kunt, A., Maksimovic, V., 2001. Capital structure in developing countries. Journal of Finance 56, 87-130.

Boubakri, N., Cosset, J-C., Guedhami, O., 2005. Liberalization, corporate governance and the performance of privatized firms in developing countries. Journal of Corporate Finance 11 (5), 767-790.

Cetorelli, N., Gambera, M., 2001. Banking market structure, financial dependence and growth: international evidence from industry data. The Journal of Finance 56, 617-648.

Cheung, W. K., Wei, K.C., 2006. Insider ownership and corporate performance: Evidence from the adjustment cost approach. Journal of Corporate Finance 12, 906-925.

Claessens, S., Djankov, S., Fan, J.P.H., Lang, L.H.P., 2002. Disentangling the incentive and entrenchment effects of large shareholdings. Journal of Finance 57, 27412771.

D’Auria, C., Foglia, A., Reedtz, P., 1999. Bank interest rates and credit relationship in Italy. Journal of Banking and Finance 23, 1067-1093.

Degryse, H., Ongena, S., 2005. Distance, lending relationships, and competition. Journal of Finance 60, 231-266.

Dell'Aricia, G., Marquez, R., 2004. Information and bank credit allocation. Journal of Financial Economics 72, 185-214.

Demirgüç-Kunt, A., Maksimovic, V., 1998. Law, finance and firm growth. Journal of Finance 53, 2107-2137.

Demirgüc-Kunt, A., Maksimovic, V., 1999. Institutions, financial markets, and firm debt maturity. Journal of Financial Economics 54, 295-336.

Demirgüc-Kunt, A., Laeven, L., Levine, R., 2004. Regulations, market structure, institutions, and the cost of financial intermediation. Journal of Money, Credit, and Banking 36, 593-622.

D’Souza, J., Megginson, W., Nash, R. 2005. Effect of institutional and firm-specific characteristics on post-privatization performance: Evidence from developed countries. Journal of Corporate Finance 11 (5), 747-766.

Fama, E.F., French, K.R., 2002. Testing trade-off and pecking order predictions about dividends and debt. The Review of Financial Studies 15 (1), 1-33.

Fan, J.P.H., Titman, S., Twite, G., 2006. An international comparison of capital structure and debt maturity choices. AFA 2005 Philadelphia Meetings Available at SSRN: http://ssrn.com/abstract=423483 .

Flannery, M.J., Rangan, K.P., 2006. Partial adjustment toward target capital structures. Journal of Financial Economics, 79 (3), 469-506.

Frank, M., Goyal, V.K., 2003. Testing the pecking order theory of capital structure. Journal of Financial Economics 67, 217-248.

Gaud, P., Jani, E., Hoesli, M., Bender, A., 2005. The capital structure of Swiss companies: An empirical analysis using dynamic panel data. European Financial Management 11 (1), 51-69. 
Giannetti, M., 2003. Do better institutions mitigate agency problems? Evidence from corporate finance choices. Journal of Financial and Quantitative Analysis 38 (1), 185-212.

Harris, M., Raviv, A., 1991. The theory of capital structure. Journal of Finance 46, 297355.

Hovakimian, A.G., Opler, T.C., Titman, S., 2001. The debt-equity choice: an analysis of issuing firms. Journal of Financial and Quantitative Analysis, 36 (1), 1-24.

Jalivand, A., Harris, R.S., 1984. Corporate behavior in adjusting to capital structure and dividend targets: an econometric study. Journal of Finance 39, 127-145.

Jensen, M., 1986. Agency cost of free cash flow, corporate finance and takeovers. American Economic Review 76 (2), 323-329.

Kremp, E., Stöss, E., Gerdesmeier, D., 1999. Estimation of a debt function: evidence from French and German firm panel data in A. Sauvé and M. Scheuer (eds.), Corporate Finance in Germany and France (Frankfurt-am-Main and Paris: Deutsche Bundesbank and Banque de France).

La Porta, R., Lopez-de-Silanes, F., Shleifer, A., Vishny, R.W., 1997. Legal determinants of external finance. Journal of Finance 53, 1131-1150.

La Porta, R., Lopez-de-Silanes, F., Shleifer, A., Vishny, R.W., 1998. Law and finance. Journal of Political Economy 106, 1113-1155.

La Porta, R., Lopez-de-Silanes, F., Shleifer, A., Vishny, R.W., 2000. Investor protection and corporate governance. Journal of Financial Economics 58, 3-27.

La Porta, R., Lopez-de-Silanes, F., Shleifer, A., Vishny, R.W., 2002. Investor protection and corporate valuation. Journal of Finance 57, 1147-1170.

Leary, M., Roberts, M., 2005. Do firms rebalance their capital structure?. Journal of Finance 60 (6), 2575-2619.

Levine, R., 1998. The legal environment, banks, and long-run economic growth. Journal of Money, Credit, and Banking 30, 596-620.

Levine, R., 1999. Law, finance and economic growth. Journal of Financial Intermediation 8, 8-35.

Miguel, A. de, Pindado, J., 2001. Determinants of capital structure: new evidence from Spanish panel data. Journal of Corporate Finance 7, 77-99.

Myers, S., 1977. Determinants of corporate borrowing. Journal of Financial Economics 5 (2), 147-175.

Myers, S., 1984. The capital structure puzzle. Journal of Finance 34, 575-592.

Myers, S., Majluf, N., 1984. Corporate financing and investment decisions when firms have information that investors don't have. Journal of Financial Economics 13 (2), 187-221.

Ozkan, A., 2001. Determinants of capital structure and adjustment to long run target: Evidence from UK company panel data. Journal of Business, Finance \& Accounting 28 (1), 175-198.

Petersen, M., Rajan, R., 1994. The benefits of lending relationship: evidence from small business data. Journal of Finance 49, 3-37.

Petersen, M., Rajan, R., 1995. The effect of credit market competition on lending relationships. Quarterly Journal of Economics (May), 407-443

Qian, J., Strahan, P.E., 2007. How law and institutions shape financial contracts: The case of bank loans. Journal of Finance 62, 2803-2834.

Rajan, R.G., Zingales, L., 1995. What do we know about capital structure? Some evidence from international data. Journal of Finance 50 (5), 1421-1460.

Rajan, R.G., Zingales, L., 1998. Financial dependence and growth. American Economic Review 88, 559-586. 
Shyam-Sunder, L., Myers, S.C., 1999. Testing static tradeoff against pecking order models of capital structure. Journal of Financial Economics 51, 219-244.

Stulz, R., 1990. Managerial discretion and optimal financing policies. Journal of Financial Economics 26, 3-27.

Titman, S., Wessels, R., 1988. The determinants of capital structures choice. Journal of Finance 43, 1-19.

Welch, I., 2004. Capital structure and stock returns. Journal of Political Economy 112 (1), 106-131. 